\title{
The Role of Culture in the Survival of Traditional African System of Communication: A Case Study of Yoruba Tribal Group in Nigeria
}

\author{
I.S. Popoola \\ Department of Mass Communication, Faculty of Social Sciences, P. O. Box 239 (Unilag P.O), \\ University of Lagos, Akoka - Yaba, Lagos, Nigeria \\ Mobile: 234-08023405801, E- mail: tayonigeria@yahoo.com
}

KEYWORDS Culture; technology; mass communication; language

\begin{abstract}
The globalization trend has eaten so deep into our culture and tradition as emerging information technologies now constitute a serious threat to the survival of various means by which African people disseminated information before the advent of the modern means of mass communication. As a matter of fact, the new information technologies have grounded some of the ways by which the Yoruba race in Nigeria communicated with each other before the advent of print and electronic media i.e. newspapers, magazines, radio and television. Apart, the phenomena growth both in terms of size and population of various African communities has equally aided the massive erosion of some of the hitherto cherished indigenous means of communication. However, in spite of the considerable in-roads which new information technologies have made into traditional African communication, it is a thing of joy that there are some aspects of the traditional means of communication which have refused to bow to the new information technologies. This is due to the power in the mother tongue language, which is the language of communication. This is the focus of the paper. Thus, the objective of the study is to reveal the changing phases of traditional African communication. The study is carried our through the interview survey method of conducting research.
\end{abstract}

\section{INTRODUCTION}

A little over four decades ago, a renowned communicator, Marshall Mcluhan took a cursory look at the impact of technology on communication and arrived at his widely quoted phrase that "technology has reduced the world to a global village". This is a truism because today, through the impact of technology, the Cable News Network (CNN), can beam and has been beaming several events live to millions of television audience in various parts of the world. Our world today is awash with information. We are daily confronted with myriad of new information technologies such that many scholars have declared that we are now living in the age of information explosion.

Just as technology has made it possible for events to be beamed live to television audience or radio listeners across the world, in the same way, it has equally made it possible for events early in the day to be reported later that same day through the print media i.e. evening newspapers. Such is the magnitude of the quiet revolution which technology has brought to information dissemination.

In the face of the new information technologies, the pertinent questions to then ask are;
What impact has the new information technologies made on traditional African communication? Do the new information technologies constitute any threat to the survival of African culture and tradition? What does the future hold for African traditional means of communication in the face of the emerging information technologies and the crave for globalization? These are the probing research questions for the study.

\section{METHODOLOGY}

This paper is a product of six months intensive research carried out between the months of June - December 2002 across three states in the South Western part of Nigeria, namely: Ekiti, Osun and Lagos. It is instructive to note that the Yoruba tribe is one of the three major ethnic nationalities in Nigeria.

The research was carried out through face to face interview survey technique in which a set of questions were drawn up on various aspects of traditional communication on which selected members of the population were requested to react.

The targeted samples who reacted to the research instrument or questionnaire were royal fathers who by African culture and traditions are 
regarded as the custodians of the people's culture.

While drawing up the research instrument, conscious efforts were made to ensure standardization of the researcher's questions by ensuring that interviewers ask exactly the same questions in the same way.

To ensure reliability of the results of the study, the samples were drawn from rural, semiurban and urban communities in the three states. This provided us the opportunity of generalizing the outcome of the research.

\section{THEORETICAL FRAMEWORK}

$i$. What is Communication? One of the concepts, which have received so much scholarly attention over the years, is that of communication. The concept is so important in the field of Mass Communication to the extent that attempts by experts and leading communication scholars to provide a universally accepted definition of communication have thus become a magnetizing pull.

Blake and Haroldsen (1975) contend that: "While communication is a widely used concept, one must emphasize that there is no complete agreement among observers as to the dimensions of the term."1

Our goal in this paper therefore is to provide some of the relevant postulations of international scholars which are relevant to the subject matter of this paper.

In one of the most widely quoted definitions of communication, Blake and Haroldsen (1995) opined that it is the: "The transmission of information, ideas, emotions, skills etc by use of symbols - words, pictures, figures, graphs, etc. It is the act or process of transmission that is usually called communication"' .

Richard (1922, quoted by Janet 1988 and Okogbe 2002) also described communication as "a discrete aspect of human enterprise". He points out that: "Communication takes place when ones mind so acts upon its environment that another mind is influenced and in that other mind, an experience occurs which is like the experience in the first mind"'.

Also contributing, Ault, Warren and Edwin (1965) defined communication as "the art of... making things common knowledge"4. Thus, communication could be seen as a process of creating and transmitting messages. It is also sharing meanings between human beings either through verbal and non verbal cues. Therefore, communication could be intrapersonal or interpersonal. Bittner (1989) describes intrapersonal communication as "communication within ourselves"5. He stated that early humans used their senses to help them understand their world and to develop perception and judgment.

"They learned that on a hot rainy day, they could seek shade to cool off. When it was cold, they could build a fire. The process of sunlight entering the eye and communicating brightness to the central nervous system, the tactile sense organs communicating the feeling of cool air, the thought processes of deciding whether to brave the cold or build a fire, stay inside or go outside, were all the result of communication taking place within the individual" 6 .

Interpersonal communication on the other hand is a communication in a face-to-face situation. A typical interpersonal communication involves the sender, the medium, the message, the receiver and feedback. Thus, everyday, we use interpersonal communication. However, as Bittner (1989a) pointed out, "the number of people we can reach with our ideas is limited if this is the only means of communication available"7. Thus, the limited number of people that could be reached through interpersonal communication led to evolution of another process through which a large collection of people could be reached which is known as Mass Communication.

ii. Traditional Communication: An important aspect of human life is the fact that we communicate. Even though this is the age of globalization or modernization. However, before the advent of the modern means of Mass Communication, the indigenous people in various African communities carried out all the existing functions of Mass Communication: Information, education, entertainment, enlightenment, surveillance etc. The point however is that it was on a limited scale.

According to Akinfeleye, (1988) quoting Harold Lasswell: "Man has always needed something to watch over his environment and report to him on dangers, discoveries, opportunities, opinion, facts, decisions, changes and current trends - something to entertain people on broad scale, something to broaden trade and commerce"s.

In the primitive age, individuals were 
assigned to the above-enumerated tasks of the mass media. Thus, watchmen, members of tribal council... were regarded as the "communicators". iii. Yoruba: Kirk-Greene (1967), revealed through a study that "Nigeria is made up of over 400 ethnic groups inhabiting an area of $913,072.64 \mathrm{sq}$ kilometers" ". One of the three major ethnic groups in the country is the Yoruba, geographically located in the South Western part of the country. The others are Igbo and Hausa/ Fulani, inhabiting the Eastern and Northern parts of the country respectively.

Webster and Boahen (1967) noted that the Yoruba people are "bounded on the north by the Niger, on the east by Benin, on the south by the Gulf of Guinea and on the West by Dahomey" Olurode, (1994) argued that their language is Yoruba even though there are variations. They are predominantly found in Oyo, Ogun, Ondo, Lagos, Kwara and also part of Edo State"12. He further states that the 1963 Census indicated that about forty-nine percent and forty-three percent of the population in Western Nigeria were Christians and Moslems respectively.

iv. Culture: An important mark of identification of any group of people at any point in time is culture. Hence, according to Popoola (2001), "Culture is generally seen as people's way of life" 13 . That is, the mode of dressing, eating, dancing, drinking, religious beliefs etc.

Within the context of this paper, a strong factor in the survival of traditional African communication in Yoruba land remains the cultural factor. Before the advent of mass communication, all the major functions of modern mass media were carried out. For instance, surveillance, one of the modern functions of mass media was performed through talking drums. Whenever there is a danger, be it in form of invasion or war, the people would be alerted through talking drums.

Even though the new information technologies tend to relegate traditional African communication to the background, the fact remains as would be seen later in another segment of this paper that traditional African communication can never die no matter the degree of encroachment of foreign culture and modern means of Mass Communication.

\section{ORIGIN OF MODERN MEANS OF MASS COMMUNICATION IN NIGERIA}

The origin of modern means of mass communication in Nigeria began with the print medium in 1859 when the publication of Iwe Irohin, a Yoruba language newspaper commenced in Abeokuta, courtesy of a British Missionary, Rev. Henry Townsend. However, according to Wilson, (1988), production of books began in the country in 1846 when the Presbyterian mission based in Calabar, introduced the first printing machines into the country"14. There and then, several newspapers and magazines followed.

Uche, (1989) on the other hand traced the emergence of the broadcast media in Nigeria commencing with radio to "1932 when Lagos began to relay the British Empire Service from Daventry, England"15. The pervasive influence of the broadcast media was however not fully appreciated until 1959 when the defunct Western Nigeria regional government established the first television broadcasting not only in Nigeria, but also in the continent of Africa. From the Western Regional experiment, the defunct Eastern and Northern Regional governments followed same step in 1960 and 1962 respectively. Today, all the states of the federation have established their radio and television stations in addition to several others owned by private individuals. The pervasiveness of the these modern means of Mass Communication tend to overshadow the relevance of the various means by which information was disseminated in Africa south of the Sahara before the advent of these modern means of Mass Communication.

\section{CHANGING PHASES OF TRADITIONAL AFRICAN COMMUNICATION}

The various means by which information was disseminated by indigenous African people are currently undergoing changes, going by the results of six months intensive research carried out primarily to ascertain the relevance of African traditional communication system in the face of globalization.

The research which took place across three states in the South Western part of Nigeria, specifically took place in Ootunja-Ekiti, in Ikole Local Government area of Ekiti state, Ode-Remo, in Remo Local Government area of Ogun state, Sabe, Egbe and Igando towns in Alimosho Local Government area of Lagos state. The towns could be classified as rural, semi-urban and urban respectively.

The focus of the research was that of ascer- 
taining the transformation, which has taken place in the major aspects of traditional African communication in the communities. The outcome of the survey is presented in the ensuing commentary of juxtaposition of the relevance or otherwise of the major aspects of traditional African communication.

i. Folktale: This is one of the major aspects of traditional African communication, which is still relevant not only in the surveyed communities, but albeit, the entire Yoruba land where it is called "Alo".

In the words of His Royal Highness (HRH), Oba Joseph Adelola Fagbamila II, the Olootunja of Ootunja-Ekiti:

Folktale is used to communicate old stories to both old and young children. This is usually done in the evening after the day's work. We would gather ourselves family by family and thrill ourselves with folktale. It is a tradition, which has passed through several generations. It is still very relevant in our community today because we use it to teach morals and check some abuses and other things.

However, investigation revealed that the practice of folktale is popular in the rural areas while in urbanized towns such as Egbe, Igando and Sabe communities in Lagos state, the practice is seldomly observed due to the metropolitan nature of the state and stress. Thus, in urban towns, the common scenario is that 'Soap Opera', cartoons and kiddies programme on the television have replaced the folktale or bedtime stories which rural parents used to tell their children. This explains one of the reasons why a major problem of urbanization is due to absence of parental teaching concerning morality. ii. Poetry: Poetry is another old aspect of traditional African communication that is still very relevant in the day to day life of the people of the surveyed communities. According to Oba Fagbamila, members of the community used poetry a lot especially cognomen otherwise called "Oriki". Oriki, according to the first class oba "is a kind of descriptive nickname through which we gain insights into what had happened in the past in each family. Family history, according to our culture, is recorded in cognomen. Therefore, it is very historic". It was discovered that the emergence of modern forms of communication has no adverse effect on poetry.

iii. Market: one of the avenues of information dissemination in those days that is still relevant today is market. In some of the surveyed towns, especially, the rural and semi-urban, market was cited very close to the oba's palace. According to the Alaye-Ode of Ode-Remo, Oba Funso Adeolu and Oba Fagbamila II, "market is ideally a place established for the purpose of buying and selling. However, it is also a good avenue for dissemination of news.

According to Oba Adeolu who acted the role of Chief Eleyinmi in the popular NTA's programme, "Village headmaster",

Market is a good avenue to disseminate news. Whenever I have news which I want the people to get as soon as possible, all I need doing is to send the town crier to parakoyi, that is, the chief in Charge of the market who in turn will call the leaders in each segment of the market to tell them and from there, the message gets to the people.

The view of Oba Fagbamila is however slightly different. He said:

Whenever I have anything to tell my subjects, since the market is very close to the palace, what I often do is to give the information to the palace messenger who in turn will carry it directly to the people in the market.

However, whether the oba's message is sent through the Chief in charge of the market or the palace messenger, the fact remains that the market was and still remain a good avenue of information dissemination as virtually all families in the village will come for shopping. Family attendance in the market is high because it is not open every day but once in every five days.

Oba Fagabmila further revealed that the nearness of the market to the palace helps to kill boredom and loneliness. He pointed out that the noise from the market breeds' life to the palace. "That is why in most towns till today, markets are sited very close to the palace. It has become part and parcel of an age long tradition and culture", he added.

iv. Drums: Music played a lot of role in the traditional African communication and is still relevant till today. Various forms of drums are available in all the surveyed communities. The list ranges from "Gangan" otherwise known as talking drum to "Gbedu", the Oba's drum, "Balufon", the "Oshugo" among others.

According to Oba Adeolu, "we used to communicate and still communicating through drums. When you are at your place of work and 
you suddenly hear the sound of the drums, the way the drum is beaten will convey you a message. For example, the music of "Oshugo" will tell you about the burial of an important member of the community while 'Gbedu', the Oba's drum, is beaten when an oba joins his ancestors or a new one is crowned".

The former TV actor further revealed that whenever 'Gbedu' drum is being beaten, no other drums could be beating at that particular point in time.

On the talking drum, 'Gangan', Oba Fagbamila stated that it's also very useful in information dissemination adding that when a visitor approaches the Oba's palace, the man in charge of the talking drum will beat it to alert the oba that a visitor is approaching the palace. Not only that, if there is going to be war, it is the talking drum that is used to communicate to the town's people. In that way, the people get the message and they react to it appropriately". Thus, drums could be beaten in different styles for different purposes. Members of 'Ogboni' confraternity could use it as a call for a meeting as it's being practice. These drums are so powerful that the sound they produce can travel almost one kilometer, especially during harmattan season.

It is therefore interesting to note that the custodians of the people's culture have refused to allow the modern music of western origin to dislocate their cherished tradition.

v. Masquerade: In Yoruba mythology, masquerade is perceived first as representative of the departed ancestors and secondly as a medium of entertainment. In Igando, Alimosho local government area of Lagos state, the traditional ruler, Oba Lasisi Gbadebo Gbadamosi said there are seven different types of masquerades representing seven compounds or clans. Each of them comes out to perform at events such as "oro festival" or 'Egungun' festival. It is however instructive to note that each of the masquerades convey oba's message(s) to the people in each clan.

In Ootunga township, Oba Fagbamila revealed that the only masquerade they had comes out only when an old man or women dies. His words:

When an old man or woman dies, it is the masquerade that conveys the message to the people. When they see the masquerade, they quickly decode the message that something has happened.
The royal father said in the olden days, special masquerades were used to convey some special messages such as war as well as the death of an oba. He was however quick to add that it is mainly used today as a form of entertainment.

However, in Igando, Oba Gbadamosi added another dimension to the functions of masquerade in his community as he pointed out that when people are quarrelling over a piece of land or if we urgently want to control or curb a violence, we would bring out 'Oro masquerade'. Immediately the 'Oro masquerade' appears at the scene, everybody will disperse without any argument. On hearing the sound of 'Oro masquerade', instant peace is restored because it is highly dreaded which women must not see". vi. Town Crier: In all the surveyed communities, town criers are still in active use. They play the role of modern radio by announcing important messages. All the royal fathers claimed that whenever they have message to pass to the people, it is the town crier that will take the 'gong' and beat it. Immediately that is done, everybody will be attentive to receive the oba's message.

Even when it is thought that the large size of some of the surveyed communities such as Igando, Egbe, Igbobi, Sabe and Ode-Remo might have rendered the effectiveness of town crier useless, it was learnt that a motorized town crier is then introduced.

Defending the relevance of town crier in the face of the pervading influence of radio and television, Oba Fagbamila said:

The reason why we find it difficult to discard the town crier is this. If we say we would use radio, we would have to travel to Ado-Ekiti, a journey of about one and half hours. If the message is urgent, how do we pass it to the people under such situation as quickly as possible? Even if we get to Ado - Ekiti, NEPA may rob our people from getting the message. It will then mean that only those whose radio uses battery will get the message and they may distort it when relying it to the people.

The story is the same in all the other surveyed communities. For instance, Ode-Remo is about one hour, forty-five minutes drive to Abeokuta, where the state radio and television stations are located. In Lagos, it takes about an hour for vehicles to travel either from Egbe, Igando, and Sabe, to Ikeja, the state capital where radio Lagos and television stations are located due to traffic jam. 
Thus, the town crier is one of the unique forms of traditional communications, which is undergoing transformation in order to catch up with the trend of events in the society. Even advertisers who are desperate to penetrate the grass roots use motorized town crier in the urban parts of the surveyed communities. Likewise, politicians and political parties.

vii. Wooden Gun: Another traditional instrument of communication is the usage of wooden or Dane gun. This is however peculiar to rural town ship such as Ootunja. When an important chief or member of the hunters died, it is traditional to honour the departed soul with gun salute. Immediately the people hear the sound of the gun, the meaning is easily decoded.

viii. The use of Aroko: "Aroko" is a form of local communication often used whenever there is an urgent message sent by the Oba. 'Aroko' usually comprise Kolanut, a bottle of drink, Bitter cola and little oil, wrapped up with a bunch of leaves. This traditionally represents a letter from the oba through his messenger to his chiefs whenever there is an urgent matter to discuss or passed across. When the receiver gets it, he must comply immediately.

ix. Pepper: Pepper was one of the means through which news of an impending war with another community could be broken. All the royal fathers agreed that before the advent of civilization, when a community intends to wage war with another community, all the head of the community needs doing is just to rap two or three pieces of pepper with leaf and send it to the head of the community to be engaged in war. It is however no longer in use. Not even Ife and Modakeke, which engaged each other in communal war in the South West, sent pepper to each other before going into war. Thus, it is no longer relevant in today's world.

$x$. Palm Front: In the rural and semi-urban towns of the surveyed communities, notably Ootunja and Ode-Remo, palm front is used as another form of communication. Take for instance, if some people are fighting over a plot of land or an economic tree, such as Mahogany, 'Iroko' etc, once palm front is tied round the tree in the case of economic tree or any other tree in the case of dispute over land, it signifies that nobody should touch the tree or do anything on the land.

\section{CONCLUSION}

From this survey, it could be seen that this paper has debunked the notion that the African traditional communication is outmoded, as Wilson (1988) pointed out, quoting Ronald Escarpit (1968) and Colin Cherry (1975), "no newly introduced mode of communication or combination of new modes wholly replace or supplant the traditional ones. The fact is that they supplemented the old ones or replace some of their functions but never all their functions" ${ }^{15}$.

The survey has therefore proved the relevance of traditional media of communication in the day-to-day administration of the people, especially at the grass roots.

One of the secrets behind the survival of traditional African Communication as revealed by the research is the language of communication, in this case, Yoruba. It is instructive to note that except the few vernacular newspapers operating in the southwest, all the remaining modern media of mass communication use English as their language of communication. Thus, while traditional African communication system carries everybody along, both literate and illiterate, the modern means of mass communication can only influence the educated elite. Furthermore, the traditional system of communication in Yorubaland refused to bow to modern mass communication due to the Yoruba culture of socializing the young ones into on-going culture and tradition in the various communities.

Jaros (1973), quoting Jean Jacques-Rousseau, an outstanding advocate of childhood political indoctrination says "the young be effectively socialized"16. Thus, a strong factor in the survival of traditional African communication in Yorubaland could be attributed to the conscious efforts of socializing agents, especially that of parents and opinion leaders to socialize the young ones into the existing culture and tradition in the communities.

The point should also be made that most of the traditional system of communication took place through verbal communication. Even though, the system is rooted in an authoritarian system of monarchy, it is strongly recommended that the system be preserved in the interest of our cherished culture and tradition.

\section{NOTES}

1. Blake and Haroldsen. 1975, "Communication", in Taxonomy of Concepts in Communication, New York: Hastings House publishers p. 3

2. Ibid p. 3 
3. Richard, cited in Okogbe. 2002, "Communication needs of exceptional person..." in Journal of Nigerian Languages \& Culture, Vol. 4, p. 110.

4. Ault et al. 1965, Introduction to Mass Communication, New York: Dodd Mead and Co.

5. Bitner. R. John. 1989, Mass Communication: An Introduction, New Jersey: Prentice hall, eaglewood Cliffs. p. 8

6. Ibid p. 8

7. Ibid p. 10

8. Akinfeleye. 1988, quoting Harold Lasswell, buttressing the fact that all the major functions of mass media were performed in traditional societies, prior to the advent of modern mass media. See Akinfeleye "Media tool for National Development" in Contemporary Issues in Mass Media for National Development and National Security, Lagos: Unimedia publications Ltd p. 48

9. Kirk - Greene, A. H. M. 1967, "The peoples of Nigeria", African Affairs, Vol. 1, 66 No 262, Jan p. 4

10. Webster, J. Band Boahen, A. A. et al. 1967, West Africa since 1800, England: Longman Group Ltd p. 62

11. Olurode, Lai. 1994, "The Youba as a group", in Nigeria Heritage, Lagos: Rebonik Publications Ltd p. 16

12. Popoola, Tayo. 2001, Introduction to Government, Lagos: Corporate Lifters International

13. Wilson, "Toward Integrating Traditional and Modern Communication System" in Contemporary Issues in Mass Media for Development and National Security, Lagos: Unimedia Ltd, 1988 p. 209

14. Uche, L.U. 1989, Mass Media People and Politics in Nigeria, New Delhi: Concept Publishing co. p. 36

15. Wilson, quoting Ronald Escarpit, on the survival of traditional African communication in "Towards
Integrating Traditional and Modern communication Systems in R. A. Akinfeleye (ed) Contemporary issues in Mass Media.

16. Dean Jaros. 1973, Socialization to politics, Basic Concepts in Political Science, Lagos: Thomas Nelson publishers, p. 11

\section{REFERENCES}

Akinfeleye, A Ralph. 1988. "Media Policy: Tool For National Development" in Contemporary Issues in Mass Media for Development and National Security, R. A. Akinfeleye (ed). Lagos: Unimedia Publications Ltd.

Bittner, R. John. 1989. Mass Communication, An Introduction. New Jersey: Prentice Hall, Eaglewood Cliffs

Blake, Read H and Haroldsen, Edwin O. 1975. A Taxonomy of Concepts in Communication. New York: Hastings House publishers.

Edwin Emery, Phillip H. Ault and Warren K. Agree. 1965, Introduction to Mass Communication. $2^{\text {nd }}$ edition. New York: Dodd Mead and Co.

Jaros, Dean. 1973. Socialization to politics, Basic Concepts in Political Science. Lagos: Thomas Nelson publishers.

Okogbe, Tola Patrick. 2002, "Communication Needs of exceptional persons: The problems and Prospects of the Mentally retarded", Journal of Nigerian Languages and Culture, 4.

Uche, Luke Uka. 1989. Mass Media People and Politics in Nigeria. New Delhi: Concept Publishing Co.

Wilson, Des. 1988. "Towards Integrating Traditional and Modern Communication Systems" in Contemporary Issues in Mass Media for Development and National Security, R. A. Akinfeleye (Ed.). Lagos: Unimedia Publications Ltd. 